\title{
KLAUSULA EKSONERASI DALAM PERJANJIAN KREDIT ANTARA PT. MANDIRI PERSERO (TBK) SEMARANG DENGAN WIBOWO S.E. DAN SITI AISYAH (Studi Kasus Putusan No. 8 K/Pdt/2013)
}

\author{
Hellen Rumiris \\ (Mahasiswi Program S1 Fakultas Hukum Universitas Tarumanagara) \\ (E-mail: hellenrumiris@gmail.com) \\ Stanislaus Atalim \\ (Corresponding Author) \\ (Dosen Hukum Perjanjian Fakultas Hukum Universitas Tarumanagara, Meraih Sarjana Hukum dari \\ Fakultas Hukum Universitas Indonesia, Magister Hukum dari Fakultas Hukum Universitas Indonesia, \\ Doktor Hukum dari Fakultas Hukum Universitas Parahyangan)
}

\begin{abstract}
Granting credit by the bank to the society greatly helps to develop a business that is run by community both individuals and legal entities. The government of the Republic of Indonesia has intructed banking to provide credit facilities especially for the middle and lower businesses. Banking credit agreement is a standard contract made by the bank by almost not giving freedom at all to the other parties to do negotiation for the requirements offered. This type of research using a normative juridicial research. This research aims to analyze the exoneration clauses in a credit agreement between PT. Bank Mandiri Persero (Tbk) Semarang with Wibowo, S.E. and Siti Aisyah. The bank credit agreement is the legal agreement to the Article 1320 of Indonesian Civil Code. However, the exoneration clauses listed on it contradicts some basis in the law agreement and also violates the provisions of Article 18 of The Consumer Protection Act. Clauses in a credit agreement are made to regulate the rights and the obligatons of the parties so that reasonable risk sharing occures between the bank and the customer. In fact, exoneration clauses are often abused by businessman attempting to diminish, divert and even refuse responsibility. The result of this research concludes that: First, the Government must provide more limits on the using of exoneration clauses through revision of The Consumer Protection Act. Second, PT. Bank Mandiri (Tbk) Semarang must be more meticulous and careful to determine contents of credit agreement.
\end{abstract}

Keywords :Standard Contract, Exoneration Clause, and Bank Credit Agreement. 


\section{PENDAHULUAN}

\section{A. Latar Belakang}

Manusiia sejaak dilahiirkan sampaai meninggaal dunia memiliki kecenderungaan untuk sellalu hidup bersama dalam suaatu pergaulan masyarakaat. Kecennderungan untuk hidup beersama teersebut laahir darii aadanya kepentingaan yaang dihaarapkan daapat dipeenuhi ooleh perrorangan atauu kelompok lainn dii luuar diirinya. Faakta inni oleeh filsuf Aristoteles diseebut seebagai "zoon politicon" atauu manuusia sebagaii makhluuk sosiial daan politiik. Keehidupan bersama dalam tatanaan bermasyarakaat menimbullkan adaanya interaksi, kontaak ataau hubungaan satu sama lain. ${ }^{1)}$

Interaaksi sosiial dalaam kehiduupan bermasyarakaat tersebut menimbulkan hak dan kewajiban yang bersifat timbaal baalik. Tidak adaa hak tanpa kewajiiban, dan sebaaliknya tidaak ada kewaajiban tanpaa haak. Dengaan kata lain, pihaak yang satu menuntuut kenikmataan atauu keleeluasaan kepaada individuu laiin, dan kewajibaan merupakaan pembaatasan atauu bebaan untuuk dilaksanakaan. ${ }^{2)}$ Saalah satuu coontoh dari interaaksi soosial yangg dpaat melaahirkan hak dan kewajiban (hubungan hukum) adalah perjanjiaan jual beli.

Perjanjiaan jual-beli mengandung asas konsensualisme yangg menjiwai hukum perjanjian. Asas itu terdapat di dalam Kitaab Undang-Undang Hukum Perdata (selanjutnya disebut KUH Perdata). Perjanjian jual-beli lahir pada detik tercapainya kata "sepakat" terhadap barang dan jasa yang ditawarkan, atau dengan kata lain kedua pihak sudah setuju. Kesepakatan antara kedua belah pihak tersebut ditandai dengan mengucapkan kata "setuuju”, "accord", "oke” dan laain sebagainya ataupun dengan menandataangani segala apa yangg terteraa diatas tulisaan (hitam di atas putih). ${ }^{3)}$

1) Sovia Hanasah, “Arti Peristiwa Hukum Dan Hubungan Hukum”, http://www.hukumonline.com/klinik/detail/lt5aebc758a2210/arti-peristiwa-hukum-dan-hubunganhukum\#_ftnref2, 7 Agustus 2018.

2) Sudikno Mertokusumo, Mengenal Hukum, (Yogyakarta: Cahaya Atma Pusaka, 2010), hal.51.

${ }^{3)}$ R. Subekti, Aneka Perjanjian, (Bandung: PT. Citra Aditya Bakti, 1995), hal.3. 
Perjanjiaan ituu terbagi dalam beberapa jenis, namun berdasarkan bentuknyaa dibagii menjaadi dua yakni perjanjian lisaan dan tertulis. Perjanjian tertulis dibagi lagi menjadi dua bagian yaitu berupa akkta dibawah taangan dan akta oteentik. Perjanjian teertulis inilah yangg biasanya diguunakan dalaam perjanjiaan krediit perbankan atauu dikenaal dengaan istilah perjanjian baku (perjanjian standar). Perjanjiaan baku dalam bahasa Belanda dikenaal dengan istilaah "standaard contract" sedangkan dalaam bahasa Inggris dikenaal dengan istilaah "standardize contract", 4 )

Perjanjiaan baku pada hakikaatnya merupakaan perjanjiaan yangg isinyaa telah distrandardisasi oleeh pelaaku usaaha dan sudaah tercetaak dalaam bentuuk formuulir-formuulir tertentuu. Salaah satuu contohnyaa adalaah perjanjiaan kredit perbankan. Nasaabah selaaku konsuumen akaan disajikaan perjanjiaan oleh pihak bank, dimana mereka akan diminta untuk meembaca perjaanjian tersebut dengan baik dan apabila ia setuju maka ia harus menandaatanganinya. Apaabila ia menoolak, maka perjanjian itu dianggap tidak adaa (take it or leave it). ${ }^{5)}$

Topiik pembahaasan perjaanjian baku berkaitan dengan 2 (dua hal) yaitu hukum perjanjiaan dan hukum perlindungaan konsumeen. Dalaam ruang lingkup hukum perlindungaan konsumen, perjaanjian bakuu diperboleehkan dan diaakui eksistensiinya selaama tidaak melaanggar syarat-syarat yangg teelah ditentuukan. Laraangan daalam penggunaan klausula baku ini dituujukan unntuk melinndungi konsuumen dari kemungkinan diterapkannya syarat-syarat yang merugikan atau tidak adil di dalam perjanjian. ${ }^{6)}$ Berdasarkan Paasal 18 UUPK, laarangan klausula baku dikaitkan dengaan dua hal, yaaitu isi dan bentuuk penuulisannya. Daari seegi isinya, perjanjiaan baku dilaarang memuaat klauusula-klausula yang tidak adil. Sedangkan dari segi bentuk penulisannya, klauusula-klausula itu harus dituliskan secaara

4) Elis Herlina dan Sri Santi, "Model Perjanjian Baku Pada Kontrak Berlangganan Sambungan Telekomunikasi Telepon Selular Pasca Bayar", Jurnal Hukum Ius Quia Iustum, No.3 Hal 3 Tahun 2016, hal.416.

${ }^{5)}$ Ibid.

${ }^{6)}$ Ibid. 
sederhana, jelas dan terang, sehiingga dapat dibaaca dan dimeengerti dengan baik oleh konsuumen.

Dalam perspektif hukum perjanjiaan, terdapat 2 (dua) jenis perjanjian yang dikenal di Indonesia, perjanjiaan bernama dan perjanjiaan tidak bernama. Macammacam perjanjiaan yang terdaapat dalaam hukum perjanjiaan yaitu jual beli (Pasaal 1457 - Paasal 1540, tukar menukar (Paasal 1541 - Paasal 1546), sewa menyewa (Paasal 1548 - Paasal 1600), persetujuan untuk melakukan pekerjaan (Paasal 1601 Paasal 1617) Perseroan (Paasal 1618 - Paasal 1652), perkumpulan (Paasal 1653 Paasal 1665), hibah (Paasal 1666 - Paasal 1693), penitipan barang (Paasal 1694 Paasal 1739), pinjam pakai (Paasal 1740 - Paasal 1743), pinjam mengganti (Paasal 1754 - Paasal 1769), bunga tetap atau bunga abadi (Paasal 1770 - Paasal 1773), untung-untungan (Paasal 1774 - Paasal 1791), pemberian kuasa (Paasal 1792 Paasal 1819), penanggungan utang (Paasal 1820 - Paasal 1850), perdamaian (Paasal 1851 - Paasal 1864). ${ }^{7)}$

Pasaal 1320 KUH Perdaata merupakaan instrumen pokok untuuk menguuji keabsahan suatuu perjanjian. Dalam pasal terseebut terdaapat 4 (empaat) syaarat yangg haruus dipenuhi yaitu: sepaakat meereka yang mengikatkan dirinya, kecakapan untuk membuat perikatan, suatu hal tertentu dan suatuu sebaab yang haalal atau diperboleehkan.

Berbeeda dengaan perjanjiaan pada umuumnya, perjaanjian baku hampir tidak memberikan kebebasan sama sekali kepada konsumen untuk melakukan negosiasi atas syarat-syarat yang disodorkan. Sementara, apaabila seseoraang sudah menandatangaani suaatu perjanjiaan maka perjanjiaan terseebut akan menjaadi undaang-undaang bagi mereeka yang mengikatan diri.

Penelitiaan ini akan mengeruucut kepaada salaah saatu contoh kaasus perjanjiaan kredit nomor RCO.SMG/160/PK-MK/2010 tertanggal 6 Juli 2010 dalam Putusan Nomor: $8 \mathrm{~K} / \mathrm{Pdt} / 2013$. yang dimana perjanjiaan tersebuut memuat klausulaa

\footnotetext{
7) Munir Fuady, Hukum Kontrak Dari Sudut Pandang Hukum Bisnis, (Bandung: PT Citra Aditya, 2001), hal.16.
} 
eksonerasi. Penulis akan menganalisa Pasal 10 Ayat (4) dalam perjanjian kredit dengan bunyi sebagai berikut:

"Dalaam hal BANK karenaa sebaab apapuun dan atas pertimbangannyaa sendiri melakukaan eksekuusi atas agunan yang teelah diseerahkan baaik pada saat ini maupun paada saat yang akaan dataang berdasarkan perjanjian kredit ini maaupun perubahannya. DEBITUR dengan ini bertanggungjawab dan membebaskaan BANK dari segala tuntutan maupun gugatan yang timbul dalam bentuuk apapun dan dari pihak manapun sebagai akibat pelaksanaan eksekusi tersebut untuk itu apabila dikemudian hari DEBITUR dengan ini memberikaan kuasa kepada BANK untuk melakuukan tindakaan-tindakaan huukum yang diperlukaan untuuk mempertahankaan haknya."

Dan Pasal 14 Ayat (2) dalam perjanjian kredit dengan bunyi sebagai berikut: "kuasa-kuasa terseebut didaalam aktaa ini merupaakan kuasa-kuasa yang tidaak daapat dicabuut kembaali dan tidaak akaan beraakhir karenaa sebaab-sebaab yaang tercantuum dalaam Pasal 1813, 1814, dan 1815 KUH Perdata, atau karena alasan apapun juga selama seluruuh hutang Debituur kepada Bank berdasarkaan perjanjiaan kredit ini beluum dibayar lunas"

Pokook permaasalahan dalaam penelitian ini adalah bahwa kedua pasal tersebut tidak memenuhi syaraat objektif sahnyaa perjanjiaan yaitu Pasal 1320 Angkaa 4 KUH Perdaata, sebaab ada pertentaangan dengan Paasal 18 Ayaat (1) dan Ayaat (2) UUPK mengeenai penguungkapan yang menimbulkaan berbagaai penafsiraan.

Dari lataar belakang yang telah diuraikan di atas, Penulis mengangkat permasalahaan tersebut ke dalaam suaatu penulisan skripsi dengan judul: "Analisis Yuridis Klausula Eksonerasi Dalam Perjanjian Kredit Pada Putusan Nomor 8 K/Pdt/2013 Ditinjau Dari Perspektif Pasal 1320 Kitab Undang-Undang Hukum Perdata".

\section{B. Perumusan Masalah}

Bagaimaana klaausula eksonerasi dalaam perjanjiaan kredit nomor RCO.SMG/160/PK-MK/2010 tertanggaal 6 Juli 2010 ditinjau dari syaarat-syaarat 
sah perjanjiaan Pasal 1320 KUH Perdata pada Putusan Mahkamah Agung Nomor 8 $\mathrm{K} / \mathrm{Pdt} / 2013$ ?

\section{Metode Penelitian}

\section{Jenis Penelitian}

Daalam suaatu penelitiaan hukum paada umumnyaa dikenaal metode penelitiaan hukum normatiif dan metode penelitiaan hukum empiriis. Metode yang Penulis gunakaan adalah metode penelitiaan hukum normatif.

Menuruut Soerjono Soekanto daan Sri Mamudji, penelitian hukuum normatif adalah suaatu prroses untuuk meneentukan suuatu atuuran huukum, asas-asas huukum, mauupun dokktrin-doktrin huukum untuuk menjawaab permasaalahan hukuum yang dihaadapi. ${ }^{8)}$

Penelitiaan hukuum normatiif disebut juga sebagaai peneelitian kepuustakaan dilakukan dengaan caraa meneliti bahan-bahaan pustaaka ataau data sekundeer saja. Soerjono Soekanto dan Sri Mamuji menyatakaan bahwa penelitiaan huukum normatif melipuuti:

a. Penelitiaan terhadaap asas-asass hukum.

b. Penelitiaan terhaadap sisstematik huukum.

c. Penelitiaan terhadaap taraaf sinkroniisasi verrtikal dan horrisontal.

d. Perbandingaan huukum.

e. Sejaarah hukum. ${ }^{9)}$

\section{Sifat Penelitian}

Ilmuu Huukum mempunyaai kaarakter yang khaas, yaaitu sifaatnya yang normatif, praktik dan preskriptif. Peneliitian yang dikajii Penuulis merupakan penelitiian yang bersifat preskriptiif yang dimaksudkan untuk memberikan

\footnotetext{
${ }^{8)}$ Soerjono Soekanto dan Sri Mamudji, Peneltian Hukum Normatif Cetakan ke-13, (Jakarta: PT. Raja Grafindo Persada, 2011), hal.14.

9) Ibid, hal.14.
} 
preskriipsi (penilaaian) mengenaai beenar atau saalah aatau aapa yang seeyogyanya menuurut huukum terhaadap faakta ataau periistiwa huukum.

\section{Jenis Pengumpulan Hukum}

Sebagaimaana jeenis peneelitian yang digunaakan daalam penelitian normatif adalah:

a. Bahaan hukum primeer merupakan bahaan hukum yang bersifaat autoritatif yaitu normaa, kaidaah daasar, dan peraturaan perundaang-undangaan. Peraturan perundang-undangan yang berkaitan dengaan juudul peenelitian yakni:

1) Kitab Undaang-Undaang Hukum Perdataa;

2) Undaang-Undaang Nomor 8 Tahuun 1999 tentang Perlindungaan Konsumen;

3) Putusan Mahkamah Agung Nomor: 8 K/Pdt/2013.

b. Bahaan hukuum sekuunder meerupakan bahan hukum yang memberikan penjelasan atauu pemahaman teerhadap bahan hukum primer (peraturan perundanng-undanngan). Berbenntuk buuku-buku yang ditulis oleh para sarjana hukum, literatur hasil penelitian, jurnasl-jurnal hukum, artiikel-artikel hukum yang memilikii hubungann dengann masalah yang dibaahas.

c. Bahan non-hukum adalah bahan-bahan yangg digunaakan dalam peenelitian ini menggunakaan bahan non hukum yangg bertujuan untuk memperoleh pemahaman atau mempeerkaya sudut pandang obyek yang diteliti. Bahan nonhukum tersebut meliputi Kaamus Besar Bahassa Indonesia dan wawancara.

\section{Teknik Pengumpulan Data}

Teknik pengumpulan data yang digunaakan dalaam penelitiaan ini melalui studii dokumeen atauu bahan pustaaka (library research), baik bahaan hukum primeer, bahan hukum sekundeer dan baahan non-hukum. Pengumpulan data yang digunakan dalam penelitian ini melalui studi dokumen atau bahan pustaka (library research), baik bahan hukum primer, bahan hukum sekunder dan bahan nonhukum. Dalam penelitiian hukuum normaatif, pengolahann bahann berwujudd 
kegiatann untukk mengadakann sistematisasii terhadaap bahann-bahann hukumm tertuliss.

\section{Telaah Bahan Hukum}

Teknik analisis data dalam penelitian ini adalah preskriptif dan deskriptif. Penuliis akaan memberikan penjelasan ataas penelitiaan yang dilakuukan, kemudiaan akaan memberikan argumentasii terkaiit hasil penelitiaan yang telahh dilakukaan. Dalaam meelakukan suatu penelitian hukum, dikenal adanya beberapa pendekatan-pendekatan yang digunakan dalam penelitian hukum. Pendekatanpendekatan terssebut terdiiri dari pendekataan undang-undang (statute approach), pendekataan kasuus (case approach), pendekaatan hisstoris (historical approach), pendekataan komparaatif (comparative approach), dan pendekataan koonseptual (conceptual approach). ${ }^{11)}$ Dalam melakukan analisis, Penulis menggunaakan pendekataan undang-undaang (statute approach), dan pendekaatan kasus (case approach). ${ }^{12)}$

Peratuuran perundaang-undangaan yang terkait adalah Kitaab UndaangUndang Hukum Perdaata dan Undaang-Undaang Nomor 8 Tahun 1999 tentang Perlindungan Konsumeen. Keemudian, menganaalisa keabssahan klausuula eksonerasi dalaam perjanjiaan kredit dengaan menyertakaan contoh kasus Putusan Nomor: $8 \mathrm{~K} / \mathrm{Pdt} / 2013$.

\section{PEMBAHASAN}

\section{Syaarat Sahnya Perjanjiaan}

Berdasaarkan Pasaal 1320 KUH Perdaata, perjanjiaan menjaadi sah apaabila memenuuhi persyarataan yaituu syaraat subjeektif yang terdirii dari sepakaat dan caakap. Keduaa, syaraat objeektif terdirii daari unssur suaatu hal teertentu dan

${ }^{11)}$ Mukti Fajar ND dan Yulianto Achmad, Dualisme Peneltian Hukum Normatif dan Empiris, (Yogyakarta: Pustaka Belajar, 2010), hal.187.

12) Ibid, hal.187. 
kausa yang diperbolehkaan merupakaan unsur objektif. Berikuut ini adaalah penjelasaan dari syaraat-syaraat sahnya perjanjian:

Sepakatt baagi mereeka yang mengikatkaan dirii (de toesteming van degenen die zich verbinden). ${ }^{13)}$ Kesepakataan adalaah perrnyataan kehendaak para pihaak yaang dibentuk oleh dua unsur utama yaitu penawaran dan penerimaan. ${ }^{14)}$ Penawarran merupakan pernyaataann keehendak yang mengandung usul untuk mengadakan perjanjian. Seedangkan peenerimaan meerupakan pernyataan seetuju dari pihaak laain yang ditaawari.

Kecaakapan untuuk meembuat membuat perikatan (de bekwaamheid om eene verbintenis aan te gaan). ${ }^{15)}$ Kecakappan yang dimaaksud adaalah kecakappan untuk melakukan perbuatan hukum. Pada umumnya, kecakaapan seseorang diukurr dari stanndar berikuut ini: person (pribadi) atau diukur dari standar usia keddewasaan (meerderjaring) dan rechtspersoon (badan hukum) atau diukur dari aspekk kewennangan (bevoegheid). ${ }^{16)}$ Daalam Paasal 1320 yang diimaksud tidak cakap unntuk membuaat perjanjiaan-perjanjiaan adaalah oraang-oraang yang beelum dewassa, merreka yang ditaruh di bawah pengampuan dan orang-orang perempuuan. Suubstansi “orang-orang perempuan" ini dihaapus deengan SEMA Nomoor 3 Tahuun 1963 dan Pasall 31 Undaang-Undaang Nomor 1 Taahun 1974 tentang Perkawinan yang pada kesimpulannya menyatakan usia 21 taahun adalaah usia dewasa. $^{17)}$

Suaatu hal tertenntu (een bepaald onderwerp). ${ }^{18)}$ Adaapun yaang dimaaksud dalam syarat ketiga Pasaal 1320 KUH Perdataa adalaah prestaasi yaang meenjadi pokok perjanjian. Mengenai hal atau objek tertentu dapat dirujuk dari substaansi Pasaal 1332 KUH Peerdata yaaitu haanya barang yang dapaat dipeerdagangkan

13) Agus Yudha Hernoko, Hukum Perjanjian Asas Proporsionalitas Dalam Kontrak Komersial, Cetakan Pertama, (Jakarta: Prenadamedia Group, 2010), hal.157.

14) Ibid, hal.162-163.

15) Ibid, hal.157.

16) Ibid, hal.184.

17) Ibid, hal.185.

18) Ibid, hal.157. 
saaja yang dapaat menjaadi pokokk perrjanjian. Pasal 1333 KUH Perdata yaitu suatu perjanjian harus mempunyai pokok berupa suatu barang yang paling sedikit ditentuukan jeenisnya. Tidaak menjaadi halaangan mengeenai jumlaah barang asal baraang tersebuut adaalah barrang yang dapat diperrdagangkan. Paasal 1334 KUH Peerdata yaitu barrang yang baruu ada pada waktu yang aakan daatang, dapat menjadi pokok perjanjiian.

Suaatu sebaab yang haalal ataau diperboleehkan (eene geoorloofde oorzaak). ${ }^{19)}$ Mengenai sebaab yang halaal dapaat ditinjau dari Pasal 1335 KUH Perdata yaitu suaatu perjanjian yang dibuaat taanpa sebaab ataau dibuaat dengaan seebab yang paalsu ataau terlaraang tidaak mempunyaai kekuuatan. Sebaab yang diperbolehkan maksuudnya adaalah baahwa aapa yaang henndak diicapai oleeh para pihaak haruslaah disertai dengan iktikad baaik. Selaanjutnya, Paasal 1337 KUH Peerdata menegaskan bahwa suaatu sebab adalaah terlaarang apabila dilaarang oleeh undaang-undaang, atau apabila berlawaanan deengan kesusilaan baaik ataau keteertiban umum.

Apabila suaatu perjaanjian tidak meemenuhi syarat sah Pasal $1320 \mathrm{KUH}$ Perdata baik syaarat suubjektif mauupun syaarat objeektif akan memiiliki akkibatakibaat teersendiri aantara laain: ${ }^{20)}$

a. noneksistensi, aapabila tiidak aada keesepakatan maaka tidaak adaa perjanjian.

b. vernietigbaar, aapabila perjanjiaan terseebut laahir karrena adaanya caacat keheendak (wilsgebreke) ataau kareena ketidakcakapaan (onbekwaamheid) aatau tidaak terpenuhiinya Paasal $1320 \mathrm{KUH}$ Peerdata syaarat 1 dan 2. Jiika uunsur suubjektif tidak terpeenuhi maaka perjaanjian tersebuut dapaat dibatalkaan.

c. nietig, aapabila perjanjiaan tiidak memeenuhi syaarat obbjek terrtentu aatau tidaak memiiliki kaausa aatau kausanyaa tiidak perbolehkan (Pasaal 1320 KUH
19) Ibid.
${ }^{20)}$ Ibid, hal.160-161. 
Perdaata syaraat ketiiga dan keempaat) maaka perjanjiaan terseebut baatal demi hukuum.

\section{Unsuur-Unsuur Perjanjian}

Unsuur-unsuuur daalam peerjanjian daapat dikeelompokkan ssebagai bberikut. Unsuur essensialia paada uumumnya adalaah uunsur yang meemberikan rumusan, definisi aatau pengertiaan daari suaatu perjanjiaan. ${ }^{21)}$ Unsuur ini $^{2}$ mewaakili ketentuaan-kekentuaan beerupa presstasi-presstasi yyang waajib dilaksanakaan oleeh salaah satuu atau leebih pihaak, yyang meencerminkan ssifat daari perjanjian tersebut, yang membedakan secara prinsip dari jenis perjanjiaan laainya. Contohnya adalaah perjanjiaan kredit usaha oleh perbankan yyang menganduung unsuur-unsuur essensialia dari perjanjiaan pinjam-meminjaam.

Unsurr naturalia adalaah unsurr yyang laziimnya melekaat pada perjanjiaan, artinyaa bahwa unsur yangg tanpaa dipeerjanjikan secara khuusus daalam suatu perjanjiaan secarra diaam-diam dengaan ssendirinya diaanggap ada daalam perjanjian karenaa sudaah merupakaan peembawaan aatau melekat paada perjanjian. $^{22)}$ Contoohnya perjanjiaan juaal beeli yyang menganduung unsur essensialia serta memiliki unsur naturalia yang melekat yaituu kewajiiban penjuall untukk meenanggung cacatt-cacatt tersembuunyi baraang yyang dijualnyaa.

Unsurr aksiidentalia adalaah unsuur peelengkap dalaam suaatu perjanjiaan yyang merupakaan kettentuan-keetentuan yyang dapaat diatuur secaara menyimpang oleh para pihak sesuai dengaan keehendak paara pihak, yaang merupakan persyaratan khusus yang ditentukan secaraa berssama-saama oleeh para pihak. ${ }^{23)}$ Dengan demikian, pada hakekatnya buukan meruupakan suatu bentuuk prestasii yyang haruss dilaksanaakan ataau dipeenuhi oleh parra pihaak melainkaan merrupakan faktor peelengkap darri unsur essensialiia dan naturalia. Contohnyaa: penncantuman tempaat dimanaa prrestasi hendakk dilaaksanakan.

${ }^{21)}$ Kartini Muljadi dan Gunawan Widjaja, Perikatan Yang Lahir Dari Perjanjian, (Jakarta: Raja Grafindo Persada, 2003), hal.85.

${ }^{22)}$ Ibid, hal.88-89.

${ }^{23)}$ Ibid, hal.89-90. 


\section{Asass-Asaas Perjanjiaan}

Berkaiitan deengaan asass-assas huukum perjanjiaan, teerdapat 4 (empaat) asass yaang menjadii tiiang utaama daalam pembentukkaan perjanjiaan yaaitu sebaagai berikuut.

Asass kebebaasan berrkontrak terdapatt dalam Pasaal 1338 Ayaat (1) KUH Perdataa yyang menyattakan bahwaa semuua perjanjiian yangg dibuatt secaraa sah berlakuu sebagaii undaang-undaang baagi merekaa yyang membuatnyaa. Asass kebebasaan berkontrak dimaksudkan bahwa semua pihak bebas menjalin hubungaan perikatan dengan dengan pihak manapun yang dikehendakinya termasuuk menentukan syarrat-syarrat, pelakssanaan dan benntuk perjanjiaannya dengaan ketentuaan bahwa perjanjiaan tersebut tidak boleh bertentanngan denngan peraturaan perundaang-undangaan yaang bersifaat memaksaa, baikk ketertibann umuum mauppun kesusilaan. ${ }^{24)}$ Asass kebebasaan berkontraak dapaat diartikaan bahwaa settiap orang dapat menciptakann perjanjiaan-perjanjiaan baruu yyang tidak dikenaal dalaam perjanjiaan bernamaa (perjanjiann tidaak berrnama) ddan yyang isinyaa menyimpang dari perjanjian bernama yang diatur oleh undaangundang. ${ }^{25)}$ Menuurut Sutan Remi Sjahdeini asass kebeebasan berrkontrak menurrut hukuum perjanjiian Indonesia melipuuti ruaang lingkup sebagaai berrikut: kebebassan untuuk membuuat atauu tidak membuat perjanjiian; kebebassan untuuk memilih pihak dengan siaapa ia ingiin membuuat perjanjiian; kebebassan untuuk menentuukan ataau memiliih kauusa darri perjanjiian yyang aakan dibuatnya; kkebebasan uuntuk mmenentukan oobjek pperjanjian; kkebebasan uuntuk menentuukan bentukk suatuu perjanjiian; kebebassan untuuk menerrima atauu mmenyimpangi kketentuan undaang-undaang yyang bersifatt opsiional (aanvullend, optional). ${ }^{26)}$

\footnotetext{
24) Abdulkadir Muhammad, Hukum Perikatan, (Bandung: PT. Citra Aditya Bakti, 1990), hal.85.

${ }^{25)}$ J. Satrio, Hukum Perikatan, Perikatan Pada Umumnya, (Bandung: Alumni, 1999), hal.36.

${ }^{26)}$ Agus Yudha Hernoko, Op.Cit., hal.110-111.
} 
Asass konsensuualisme seebagaimana terdaapat dalaam Pasaal 1338 KUH Perdataa Ayaat (1) berbuunyi demiikian "Semuaa peerjanjian yaang dibuuat seecara sah berlaku sebagai undang-undang bagi mereka yang membuatnya". Asass inii meemiliki pengertian bahwa suaatu perrjanjian meenjadi sah dan meengikat apabiila terjadiinya kataa sepakaat serta syarat-syarat lain yaaitu peemenuhan syarrat-syaraat Pasaal 1320 KUH Perdataa. ${ }^{27)}$

Asaas mengikatnya kontrak (pacta sunt servanda). Asas ini terdapat dalam Pasal 1338 Ayat (1) KUH Perdata. Asas ini memiliki pengertian bahwa semua perjanjian yang dibuat secara sah berlaku sebagai undang-undang bagi mereka yang membuatnya dan terikat untuk memenuhi perjanjian tersebut. ${ }^{28)}$ Selanjutnya, Pasal 1338 Ayat (3) KUH Perdata menetapkan bahwa persetujuan harus dilaksanakan menurut kepatutan dan keadilan.

Asas iktikad baik terdapat Pasal 1338 Ayat (3) KUH Perdata berbunyi: "Perjanjian harus dilaksanakan dengan iktikad baik". Asas ini memberikan pengertian bahwa para pihak harus melaksanakan perjanjian berdasarkan kepercayaan atau keyakinan yang teguh atau kemauan baik dari para pihak. ${ }^{29)}$ Terdapat 2 (dua) macam asas iktikad baik yaitu iktikad baik nisbi dan iktikad baik mutlak. $^{30)}$ Pada iktikad baik nisbi bahwa agar kiranya setiap orang memperhatikan sikap dan tingkah laku yang nyata dari subjek. Sementara pada iktikad baik mutlak, penilaian terletak pada akal sehat dan keadilan, dibuat ukuran yang objektif untuk menilai keadaan menurut norma-norma objektif.

\section{Akibat Hukum Perjanjian}

Suatu perjanjian yang dibuat secara sah akan menimbulkan akibat-akibat hukum sebagai berikut: Berlaku sebagai undang-undang bagi mereka yang membuatnya (Pasal 1338 Ayat (1) KUH Perdata), asas janji itu mengikat; Suatu

\footnotetext{
27) Ibid, hal.123.

${ }^{28)}$ Munir Fuady, Op.Cit, hal.30.

29) Salim H.S, Hukum Kontrak Teori \& Teknik Penyusunan Kontrak, (Jakarta: Sinar Grafika,

30) Ibid.
} 2003), hal.11. 
perjanjian hanya berlaku antara pihak yang membuatnya (Pasal 1340 KUH Perdata) dan perjanjian dapat mengikat pihak ketiga apabila telah diperjanjikan sebelumnya (Pasal 1317 KUH Perdata); Konsekuensinya para pihak dalam perjanjian tidak dapat secara sepihak menarik diri akibat-akibat perjanjian yang dibuat oleh mereka (Pasal 1338 Ayat (2) KUH Perdata); Perjanjian dapat diakhiri secara sepihak jika ada alasan-alasan yang oleh Perdata), yaitu seperti yang termuat dalam Pasal 1571, Pasal 1572, Pasal 1649, Pasal 1813 KUH Perdata; Janji untuk kepentingan pihak ketiga hanya mungkin dilakukan dalam 2 (dua) hal yaitu jika seseorang memberi sesuatu kepada orang lain dan jika seseorang dalam perjanjian membuat suatu janji untuk kepentingan sendiri; Dalam pelaksanaan suatu perjanjian harus dilaksanakan dengan iktikad baik Pasal 1338 Ayat (3) KUH Perdata, jadi itikad baik harus ada sesudah perjanjian itu ada; Selain mengikat untuk hal-hal yang diperjanjikan juga mengikat segala sesuatu yang menurut sifat perjanjian diharuskan oleh kepatutan, kebiasaan, atau undang-undang Pasal 1339 KUH Perdata serta hal-hal yang menurut kebiasaan selamanya disetujui untuk secara diam-diam dimasukkan ke dalam perjanjian (Pasal 1347 KUH Perdata); Pada saat menentukan isi perjanjian harus memperhatikan pembatasan umum yaitu unsur-unsur penambah baru ditambahkan, kalau sifat perjanjiannya memang membutuhkan penambahan dan yang ditambahkan itu harus sesuai dengan sifat perjanjian yang mau ditambah (Pasal 1339 KUH Perdata); Yang menentukan isi perjanjian adalah undang-undang yang memaksa, kata-kata dalam perjanjian yang bersangkutan, janji yang selalu diperjanjikan, undang-undang yang menambah/mengatur, kebiasaan dan kepatutan; Undang-undang yang memaksa kepada para pihak yang membuat perjanjian tidak diberikan kesempatan untuk memilih menggunakan atau mengesampingkan ketentuan yang bersangkutan; Undang-undang yang bersifat menambah atau mengatur berarti kepada para pihak yang membuat perjanjian ketentuan yang bersangkutan boleh secara tegas disingkirkan, tetapi jika para pihak tinggal diam, maka secara otomatis ketentuan yang bersifat mengatur mengisi kekosongan perjanjian yang dibuat tersebut; 
Konsekuensi jika undang-undang yang bersifat memaksa disampingkan para pihak dalam membuat perjanjian, maka seluruh atau bagian tertentu dari isi perjanjian yang bertentangan dengan undang-undang yang memaksa tersebut menjadi batal. $^{31)}$

\section{Klausula Eksonerasi Dalam Perjanjian Kredit (Pada Putusan Nomor 8 K/Pdt/2013)}

Perjanjian kredit perbankan (perjanjian utang piutang) dikelompokkan ke dalam perjanjian pinjam-meminjam yang pengaturannya terdapat dalam Pasaal 1754 - Pasaal 1773 KUH Perdaata. Pada umumnya, berbagai literatur hukum menempatkan perjanjian kredit perbankan sebagai perjanjian standar. Perjanjian standar atau dikenal dengan perjanjian baku adalah perjanjian yang isinya telah ditentukan atau telah distandardisasi oleh pelaku usaha sehingga konsumen hanya memiliki dua pilihan yaitu menerima atau menolak perjanjian.

Berdasarkan hasil wawancara, beliau memiliki pandangan yang berbeda bahwa perjanjian kredit dalam dunia perbankan sesungguhnya tidak dapat digolongkan sebagai perjanjian baku. Menurutnya perjanjian yang dapat dikatakan baku adalah apabila perjanjian itu tidak memberikan ruang kepada konsumen untuk berpikir, bereaksi, menawarkan atau keberatan terhadap isi perjanjian, selain mengatakan "ya" (menyetujui) contohnya adalah tiket parkir, tiket pesawat dan tiket bus.

Namun, saya sependapat dengan para ahli hukum bahwa perjanjian baku itu bukan hanya perjanjian yang mempersoalkan dua pilihan "menyetujui" atau "tidak menyetujui", melainkan ciri dari perjanjian baku itu adalah apabila suatu perjanjian tidak memberikan kesempatan sama sekali kepada konsumen untuk melakukan penawaran ulang (negosiasi) terhadap syarat dan/atau pun isi perjanjian, sehingga nasabah karena dia membutuhkan pinjaman hutang maka mau tidak mau, dia harus menyetujuinya.

31) R. Soeroso, Perjanjian Di Bawah Tangan Pedoman Praktis Pembuatan Dan Aplikasi Hukum, (Jakarta: Sinar Grafika, 2010), hal.19-23. 
Untuk mengetahui keabsahan perjanjian kredit dalam Putusan Nomor 8 K/Pdt/2013, maka penulis akan menganalisa berdasarkan Pasaal 1320 KUH Perdaata mengenai syaraat-syaraat sahnyaa perjanjiaan. Terdapat 4 (empat) syaarat saahnya suatuu perjanjiaan:

a. Syarat subjektif terdiri dari kesepakatan dan kecakapan untuk membuat perjanjian. Apabila syarat ini dilanggar maka perjanjian batal demi hukum.

1) Adanya kesepakatan para pihak. Dalam perjanjian kredit modal kerja, para pihak yaitu Wibowo, S.E. dan Siti Aisyah sebagai nasabah/konsumen dan PT. Bank Mandiri (Persero) Tbk Cq Bussines Banking Center Semarang sebagai pelaku usaha telah sepakat untuk mengikatkan diri dalam Perjanjian Kredit Modal Kerja, SPPK, dan SUPK. Kedua belah pihak menyepakati perjanjian tanpa ada unsur paksaan, kekeliruan atau penipuan.

2) Kecakapan untuk melakukan perbuatan hukum, mencakup dewasa dan tidak sakit ingatan. Dalam perjanjian kredit modal kerja, para pihak dianggap cakap menurut undang-undang untuk melakukan perjanjian ini. Dapat dilihat dari umur para pihak dan keadaannya tidak dalam pengampuan.

b. Syarat objektif terdiri dari suatu hal tertentu dan kausa yang diperbolehkan. Apabila syarat ini dilanggar maka perjanjian kredit bukanlah batal demi hukum melainkan salah satu pihak dapat membatalkan perjanjian tersebut.

1) Suatu hal tertentu. Dalam perjanjian kredit modal kerja, terdapat suatu hal yang diperjanjikan oleh para pihak yaitu pemberian fasilitas kredit modal kerja sebesar Rp 1.150.000.000,- oleh Bank Mandiri kepada nasabah yang digunakan untuk tambahan modal kerja perdagangan beras dan rice mill. Sesuatu yang diperjanjikan dalam perjanjian kredit adalah mengenai hak dan kewajiban para pihak. Nasabah/konsumen melakukan pengembalian pinjaman pokok, bunga dan biaya-biaya lainnya dengan memberikan aset atau objek jaminan hak tanggungan yaitu sertifikat hak milik atas nama Wibowo, S.E. dengan luas tanah $5425 \mathrm{~m}^{2}$, dan sertifikat hak miliki atas nama Siti Aisyah dengan luas tanah $5790 \mathrm{~m}^{2}$. 
2) Kausa atau sebab yang halal. Dalaam perjanjiaan krediit modaal kerjaa, pemberiaan fasiliitas krredit modaal kerjaa merupakaan suatuu hal yyang halaal. Sebaab aktiviitas perrbankaan seperti ini akan sangat membantu perekonomian usaha mikro dan keciil, maka dapat dikatakan perjanjian tersebut tidak bertentangan dengaan undaang-undaang, kesusilaan dan ketertiban umum. Meskipun dalam perjanjian kredit modaal kerjaa terdapaat klausula-klausula yang mengalihkan tangguungjawab bank kepadaa debiturr, namuun perjanjiaan inii tetaap menjadi suatu sebab yang halal. Jadi, setelah penulis menganalisa berdasarkaan Pasaal $1320 \mathrm{KUH}$ Perdataa, perjanjian baku tersebut telah memenuhi syaraat-syaraat sahnyaa perjanjiaan sekalipuun beberrapa passal daalam perrjanjian kreedit tersebut merugikan konsumen.

Meskipun perjanjian kredit modal kerja dalam Putusan Nomor 8 K/Pdt/2013 telah memenuhi syarat-syarat sahnya perjanjian berdasarkan Passal $1320 \mathrm{KUH}$ Perdata, namun perjanjian baku tersebut bertentangan dengan asas-asas dalam hukum perjanjian yaitu Asas Kebebasan Berkontrak (Pasasl 1338 Aysat (1) KUH Perdatsa) dan Asas Iktikad Baik (Passal 1338 Aysat (3) KUH Perdata).

Asas kebebasan berkontrak tidak hanya dimaksudkan kepada kebebasan untuk menentukan dengan siapa seseorang membuat hubungan perikatan, tetapi termasuk juga dalam menentukan syarat-syarat, isi perjanjian, pelaksanaannya dan bentuk perjanjian. Pada konsep perjanjian sederhana, perjanjian tidak hanya membutuhkan asas kebebasan berkontrak diantara pihak melainkan juga kedudukan atau posisi yang seimbang. Kesepakatan itu lahir ketika para pihak saling melakukan penawaran (bernegosiasi) hingga akhirnya perjanjian yang mereka buat dapat mengakomodir kepentingan para pihak. Proses semacam inilah yang tidak ada dalam perjanjian baku.

Bahkan, tidak ada kebebasan sama sekali bagi nasabah selaku konsumen untuk bernegosiasi atas passal-passal dalam perjanjian kredit. Bahwa benar nasabah diberikan ruang untuk membaca dan mempelajari SPPK dalam kurun 
waktu tertentu, namun konsumen tidak punya kesempatan untuk mengajukan keberatan atau meminta pengubahan terhadap pasal-pasal yang tidak menguntungkan bagi mereka. Dalam desakan kebutuhan, baik suka atau tidak suka, secara tidak langsung nasabah pasti akan menerima perjanjian itu.

Pelaku usaha cenderung melindungi kepentingannya sedemikian rupa dengan menetapkan sejumlah hak sekaligus membatasi hak-hak pihak lawan. Di sisi lain, pelaku usaha akan meminimalkan kewajiban-kewajibannya dan mengatur sebanyak mungkin kewajiban nasabah.

Di samping asass kebebassan berkontrakk, dalam pelaksanaan perjanjian kredit modal kerja dalam Putusan Nomor 8 K/Pdt/2013 ini memiliki kolerasi dengan asas iktikad baik berdasarkan Pasaal 1338 Ayaat (3) KUH Perdataa. Artinya bahwa asas iktikad baik bukan hanya sekedar asas yang diperhatikan pada saat melaksanakan perjanjian melainkan juga dalam proses pembuatan perjanjian.

Penulis merujuk Pasal 1337 KUH Perdaata dan Pasaal 1339 KUH Perdata. Pasaal 1337 KUH Perdaata berbunyi demikian: "suatu kausa adalah terlarang apabila kuasa itu dilarang oleh undang-undang, atau bertentangan dengan moral atau dengan ketertiban umum". Pasal ini memiliki makna bahwa klausul-klausul suatu perjanjian tidak boleh bertentangan dengan undang-undang, moral atau moralitas, dan/atau ketertiban umum.

Selanjutnya, Pasaal 1339 KUH Perdaata berbunyi demikian: "persetujuanpersetujuan tidak hanya mengikat untuk hal-hal yang dengan tegas dinyatakan di dalamnya, tetapi juga untuk segala sesuatu menurut sifat dari perjanjian itu diharuskan oleh kepatutan, kebiasaan atau undang-undang." Pasal ini memiliki makna bahwa selain daripada keharusan perjanjian mengandung kepatutan, kebiasaan dan undang-undang terdapat syarat lain yang harus dipenuhi dalam suatu perjanjian yaitu larangan-larangan yang sudah ditentukan oleh kepatutan, kebiasaan dan undang-undang.

Selain daripada asas kebebasan berkontrak, penulis melihat ada asas lain yang perlu juga menjadi perhatian kita yaitu asas iktikad baik (Pasaal 1338 Ayaat (3) 
KUH Perdata). Pasaal 1338 Ayaat (3) KUH Perdataa berbunyi demikian: "suatu perjanjian harus dilaksanakan dengan iktikad baik." Dari pasal tersebut kita mengetahu bahwa iktikad baik merupakan niat para pihak untuk tidak merugikan kepentingan umum.

Untuk menganalisa klausula eksonerasi yang terdapat dalam perjanjian kredit modal kerja pada Putusaan Nomor $8 \mathrm{~K} / \mathrm{Pdt} / 2013$, penulis akan menjelaskan terlebih dahulu perbedaan antara klausula baku dan klasula eksonerasi. Perjanjian yang mengandung syarat-syarat baku (perjanjian baku berklausula baku) adalah perjanjian yang meniadakan pembicaraan terhadap isi suatu perjanjian. Sedangkan, perjanjian baku dengan syarat-syarat eksonerasi (perjanjian baku berklasula eksonerasi) adalah perjanjian baku yang isinya mengalihkan atau menghilangkan tanggung jawab seseorang atas suatu akibat dari persetujuan.

Di Indonesia, pengaturan mengenai larangan klausula eksonerasi Bab V Ketentuaan Pencantumaan Klausulaa Baku Pasaal 18 Ayaat (1) menentukan bahwa Pelaku usaha dalam menawarkan barang dan/atau jasa dilarang membuat atau mencantumkan klausula baku pada setiap dokumen dan/atau perjanjian apabila: menyatakan pengalihan tanggung jawab pelaku usaha: menyatakan bahwa pelaku usaha berhak menolak penyerahan kembali barang yang dibeli konsumen; menyatakan bahwa pelaku usaha berhak menolak penyerahan kembali uang yang dibayarkan atas barang dan/atau jasa yang dibeli oleh konsumen; menyatakan pemberian kuasa dari konsumen kepada pelaku usaha baik secara langsung maupun tidak langsung untuk melakukan segala tindakan sepihak yang berkaitan dengan barang yang dibeli oleh konsumen secara angsuran; mengatur perihal pembuktian atas hilangnya kegunaan barang atau pemanfaatan jasa yang dibeli oleh konsumen; emberi hak kepada pelaku usaha untuk mengurangi manfaat jasa atau mengurangi harta kekayaan konsumen yang menjadi obyek jual beli jasa itu; menyatakan tunduknya konsumen kepada peraturan yang berupa aturan baru, tambahan, lanjutan dan/atau pengubahan lanjutan yang dibuat sepihak oleh pelaku usaha dalam masa konsumen memanfaatkan jasa yang dibelinya; menyatakan 
bahwa konsumen memberi kuasa kepada pelaku usaha untuk pembebanan hak tanggungan, hak gadai atau hak jaminan terhadap barang yang dibeli oleh konsumen secara angsuran.

Selain daripada poin-poin di atas, Pasaal 18 Ayaat (2) UUPK juga menyatakan bahwa setiap pelaku usaha dilarang mencantumkan klausula baku yang letak atau bentuknya sulit terlihat atau tidak dapat dibaca secara jelas atau yang pengungkapannya sulit dimengerti.

Dari hasil wawancara dengan narasumber, penulis hendak mengambil intisari tentang tujuan dari pengaturan larangan klausula eksonerasi yaitu meskipun nasabah/konsumen tidak membaca perjanjian baku, perjanjian itu tetap mengikat dan apabila nasabah/konsumen menandatangani untuk sesuatu yang dengan sengaja dibuat untuk kepentingan pelaku usaha/bank dalam arti memasukan jebakan-jebakan ke dalam perjanjian baku, maka oleh hukum hal ini tidak diperbolehkan. Dapat disimpulkan bahwa maksud ditempatkannya laranganlarangan terhadap klausula baku adalah untuk memberikan posisi/kedudukan yang setara antara pelaku usaha/bank dengan nasabah/konsumen berdasarkan prinsip kebebasan berkontrak.

Jika diteliti mengenaai perjanjian kredit modal kerja dalam Putusaan Nomorr $8 \mathrm{~K} / \mathrm{Pdt} / 2013$, maka akan ditemukan pasal-pasal yang tidak sejalan atau bertentangan dengan undang-undang terkait.

Pertama, Pasaal 10 Ayaat (4) berbunyi demikian: "Daalam hal BANK karenaa sebab apaapun dan atas pertimbangannya sendiri melakukan eksekusi atas agunan yang telahh diserahkan baik pada saat ini maupuun padaa saat yang akan datang berdasarkan perjanjiaan kreditt ini maupun perubahannya. DEBITUR dengan ini bertanggungjawab dan membebaskan BANK dari segala tuntutan maupun gugatan yang timbul dalam bentuk apapun dan dari pihak manapun sebagai akibat pelaksanaan eksekusi tersebut untuk itu apabila dikemudian hari DEBITUR dengaan ini memberikan kuasa kepada BANK untuk melakukan tindakan-tindakan hukum yyang diperlukan untuk mempertahankan haknya.” 
Pada dasarnya larangaan pencantumaan klausuula eksoneerasi adalah mengenai pengalihan tanggungjawab, tuntutan dikemudian hari, dan/atau resiko oleh pelaku usaha/bank kepada nasabah/konsumen. Pengalihan dalam Pasaal 10 Ayaat (4) perjanjian kredit pada Putusaan Nomorr 8 K/Pdt/2013 terletaak padaa frrasa berdasarrkan sebab apapun dan berdasarkan pertimbangannya sendiri akan melakukan tindakan-tindakan hukum terhadap aset atau objeek kekayaan nasabaah/konsumeen yyang telah menjadi objek agunan. Berdasaarkan hasil wawancara ddengan nnarasumber, padaa umumnyaa bbank akann melakukan beberapa langkaah dalaam prosess penyelesaiann kreditt macett yaituu pertama melakukan peninjauan langsung terhadap usaha kredit nasabah, kedua melakukan pemberitahuan melalui surat resmi apabila terjadi kredit macet, ketiga mencari solusi melalui proses restrukturisasi hutang, keempatt apabilaa tidakk menemukaan jalaan keluaar maka barulah bank melakukan somaasi berupa peringatan 1, 2 dan 3 daan sertaa membaantu nasaabah/konsumeen untuik mencarikan calon pembeli terhadap penjualan atas objek agunan.

Dengaan demikian, penuliis menyimpulkan bahwa pasal tersebut memenuhi Pasaal 18 Ayaat (2) UUPK yang menyatakan bahwa hendaklah pelaku usaha membuat perjanjian yang pengungkapannya dapat dipahami oleh konsumen serta menghindari klausula yang dapat menimbulkan berbagai asumsi (miss representation) dan/atau klausula yang tidak mengungkapkan maksud sebenarnya (miss disclosure). Frasa pertimbangan bank baik tersirat maupun tersurat "memaksa" nasabah/konsumen agar pertimbangan bank yang lebih diutamakan dan tidak mengupayakan atau mengutamakan pencarian solusi kepada nasabah/konsumen dengan cara melaksanakan restrukturisasi hutang.

Pasal 14 Ayat (2) dalam perjanjian kredit dengan bunyi sebagai berikut: "kuasa-kuasa tersebut didalam akta ini merupakan kuasa-kuasa yang tidak dapat dicabut kembali dan tidak akan berakhir karena sebab-sebab yang tercantum dalam Pasal 1813, 1814, dan 1815 KUH Perdata, atau karena alasan apapun juga selama seluruh hutang Debitur kepada Bank berdasarkan perjanjian kredit ini belum dibayar lunas”. 
Telahh dikemuukakan seebelumnya bahwaa berdasarkaan Pasaal 1339 terdapatt syaratt laiin yyang harrus dipenuhii ketiika membuuat suattu perjanjiaan yaituu mengeenai larangaan-larangaan yyang sudaah ditentukann oleeh kepatutaan, keebiasaan dan undaang-undaang. Larangann peenggunaan kaausa muttlak telahh diaturr melaalui beberaapa pengaturran yaaitu Intrukksi Mendagrii Nomoor 14 Tahunn 1982 tentanng Larangaan Pengguunaan Kuassa Mutlaak dan Peraturran Pemerinntah Nomorr 24 Tahuun 1997 tentang Pendaftarran Tannah. Tujuaan darii keduua peengaturan ttersebut adalahh unntuk mennghindarkan tinndakan-tinndakan pennyelundupan hukuum padaa saat juual beli tanah dan menegasskan kepaada pejaabat pemerintaah unttuk menolaak permohonann pembuataan aktaa tanaah appabila ssalah ssatu ppihak beertindak ataas dasarr suraat kuasa mutlaak yaang mana surat kuasa itu yang berisikan perbuatan hukum pemindahan hak. Penulis melihaat bahwaa Pasaal 14 Ayaat (2) perjanjiaan kreditt modal kerjaa padaa Putusan Nomorr 8 K/Pdt/2013 tersebuut merupakaan klausulaa mutlaak yyang dimaksuud dalaam intruksi mendaagri yaituu kuasa tidaak dapaat dicabuut atauu tidaak dapaat berakhir karenaa alaasan apa pun atauu disebutt jugaa dengaan kuasa mutlaak. Jelaslaah bahwaa klausulaa mutlaak itu klausuula yaang dilaraang oleeh undaang-undaang sebaab mengesaampingkan ketentuan Paasal 1813, Pasaal 1814 dan Pasaal 1815 KUH Perdataa mengenai cara berakhirnya pemberian kuasa.

Dari pandangan Hukum Perjanjian, akibat hukuum dari klausuula eksonerasi dalam perjanjian kredit modaal kerjaa pada Putusan Nomorr 8 K/Pdt/2013 adalah bataal demi hukum karenaa pencantuman klausula tersebut bertentangan dengan salaah satuu isi Pasaal 1320 KUH Perdata yaituu suatuu kausa/sebab yyang halal.

Selaain ituu jugga memiiliki kerkaaitan ataau hubungaan terhadaap pengalihaan tanggungjawaab pelakuu usaaha berrdasarkan Pasaal 18 Ayaat (1) dan Ayaat (2) UUPK bahwaa terhadaap isi suatuu perjanjian bakuu menjadii batal demi hukum apabila klasulaa-klausulaa dalaam perjanjiaan baku ttelah 
menciderrai batasann-batasann penggunaann kklausula baku dalaam undaangundaang (ttelah memenuuhi apaa yyang dilarangg oleeh undaang-undaang).

\section{PENUTUP}

\section{A. Kesimpulan}

Berdasarrkan uraian analisis di atas, maka dapat ditarik kesimpulan sebagai berikut:

Dalam perspektif Hukum Perjanjian, perjanjiaan baku berklausula eksoneraasi merupakaan perjanjiaan yyang sah karena telah memenuhi unsur syarat-syarat sahnyaa perjanjiaan yang terdapat dalam Pasaal 1320 KUH Perdaata. Namun, perjanjiaan baku berklasuula eksoneraasi tersebut bertentangan dengan Asas Kebebasaan Berkontraak (Pasaal 1338 Ayaat (1) KUH Perdaata) dan Asaas Iktikadd Baikk (Pasaal 1338 Ayaat (3) KUH Perdaata).

Dalam perspektif Hukuum Perlindungaan Konsumeen, suatu perjanjiaan baku dikatakaan berklausuula eksoneraasi apabilaa pencantumaan klausulaanya telah memenuhi kriterria-kriterria klausula eksoneraasi yyang tercantuum dalaam Pasaal 18 Ayaat (1) dan Pasaal 18 Ayaat (2) UUPK.

Berdasarkaan uraiaan-uraian dalaam bab-bab sebelumnya, menurut hemat penulis terdapat 2 (duua) pasaal dalaam perjanjiaan krediit modaal kerjaa yyang memenuhi kriteria-kriteria klausula eksonerasi yaitu. Pasal 10 Ayat (4) dalam perjanjiaan kredit memenuhi Poinn A Pasaal 18 Ayaat (1) UUPK yaituu klausulaa yyang menyataakan pengalihaan tanggungjawab pelaku usaha dan Pasaal 18 Ayaat (2) yyaitu klausula yyang pengungkapaannya suliit dipahaami oleeh konsumeen dan/atau menimbulkan berbagai asumsi, atau tidak mengungkapkaan maksuid sebenaarnya. Pasaal 14 Ayaat (2) perjanjiaan kredit bertentangann ddengan peraturann perundaang-undangaan yaituu Intruuksi Menterii Dalaam Negeeri tentaang Larangaan Ppenggunaan Klasuula Mutlaak, Peraturan Pemerintah Nomor 24 Tahun 1997 tentang Pendaftaran Tanah dan KUH Perdata (Pasal 1813, Pasal 1814, Pasal 1815 KUH Perdata). 


\section{B. Saran}

Berdasarkaan kesimpuulan diataas makaa saran yangg dapatt diberikaan aadalah ssebagai berikuut. Pelakuu usaaha dalaam hal ini PT. Bank Mandiri (Persero) Tbk Cq Bussiness Banking Center Semarang lebih memperhatikan asasasas Hukum Perjanjian yaitu asas kebebasan berkontrak dan asas iktikad baaik dalam proses pembuatan perjanjian kredit modal kerja (perjanjiaan baku) sehingga kedua belah pihak bersamaa-saama mendapatt keuntungann secaara proporrsional pada saatt melaksanakaan perjanjiian.

Pemerintah Indonesia melakukan revisi terhadap UUPK dengaan lebiih mempertegaas pengaturran mengenaai kriterria-kriterria perjanjiian baku yyang berklausula eksonerasi. Dengan adanya penegasan tersebut, diharapkaan kedepannyaa pelaku usaha dapat lebih memperhatikan klausula eksoneraasi baiik dalam prosess pembuataan perjanjiaan maupuun padaa saatt pelaaksanaan perjanjiaan.

\section{DAFTAR PUSTAKA}

\section{A.BUKU}

Fuady. Munir. Hukum Kontrak Dari Sudut Pandang Hukum Bisnis. (Bandung: PT. Citra Aditya Bakti, 2001).

Hernoko. Agus Yudha. Hukum Perjanjian Asas Proporsionalitas Dalam Kontrak Komersial. (Jakarta: Prenamenia Group, 2010)

Mertokusumo. Sudikno. Mengenal Hukum. (Yogyakarta: Cahaya Atma Pusaka, 2010).

Muhammad. Abdulkadir. Hukum Perikatan. (Bandung: PT. Citra Aditya Bakti, 1990).

Muljadi. Kartini. dan Gunawan Widjaja, Perikatan Yang Lahir Dari Perjanjian. (Jakarta: Raja Grafindo Persada, 2003). 
ND. Mukti Fajar. dan Yulianto Achmad. Dualisme Penilitian Hukum Normatif dan Empiris. (Yogyakarta: Pustaka Belajar, 2010).

Satrio. J. Hukum Perikatan, Perikatan Pada Umumnya. (Bandung: Alumni, 1999).

Soekanto. Soerjono. dan Sri Mamudji. Penelitian Hukum Normatif. Cetakan ke13. (Jakarta: PT. Raja Grafindo Persada, 2011).

Soeroso. R. Perjanjian Di Bawah Tangan Pedoman Praktis Pembuatan Dan Aplikasi Hukum. (Jakarta: Sinar Grafika, 2010).

Subekti. R. Aneka Perjanjian. (Bandung: PT. Citra Aditya Bakti, 1995).

\section{B.PERATURAN PERUNDANG-UNDANGAN}

Indonesia. Undang-Undang Nomor 08 Tahun 1999 tentang Perlindungan Konsumen (Lembaran Negara Republik Indonesia Tahun 1999 Nomor 42).

. Kitab Undang-Undang Hukum Perdata (Staatsblad Tahun 1847 Nomor 23).

. Putusan Mahkamah Agung Nomor (8 K/Pdt/2013)

\section{C.Artikel}

Herlina, Elis dan Sri Santi. "Model Perjanjian Baku Pada Kontrak Berlangganan Sambungan Telekomunikasi Telepon Selular Pasca Bayar”. Jurnal Hukum Ius Quia Iustum. No.3 Hal 3 Tahun 2016.

\section{D.Internet}

Hanasah, Sovia. "Arti Peristiwa Hukum Dan Hubungan Hukum", http://www.hukumonline.com/klinik/detail/lt5aebc758a2210/arti-peristiwahukum-dan-hubungan-hukum\#_ftnref2. Diakses tanggal 7 Agustus 2018. 